\title{
Comparative analysis about consumer rights regarding convenience food among working and non-working Women
}

\author{
S. Kundle, A. Joglekar and S. Banerjee
}

\begin{abstract}
Convenience food is multi-faceted and will continue to evolve and converge with other trends to meet the food needs and demands of society. Convenience food means more than single serve, easy-to-prepare, and easy-to-take-away products. Women consumers constitute 50 per cent of the total consumer population and approximately 80 per cent of them take decisions while purchasing products for their family. In an era of consumerism every woman prefers convenient products with additional attributes, such as foods that are healthy, ethical and comforting. The present study aimed to assess the women's knowledge about consumer's rights regarding all aspects of convenience food. The present study was carried out on 100 women (50 working and 50 non-working). A self-designed interview schedule including demographic data and knowledge about consumer's rights regarding convenience food was used to collect the data. The results of present study revealed that 68 per cent working and 52 per cent non-working women had knowledge about the consumer act, 54 per cent working and 66 per cent non-working women were agreed on production and advertisement of unhealthy convenience food should be banned by the government. The study recommends that as consumers we have the right to purchase product of our choice but while selecting products, proper care should be taken by consumers. They must ensure the nutrient content, weight, quality and manufacturing date of the products. The study also recommend awareness programme at school, college level for young consumers.
\end{abstract}

Key Words : Convenience food, Working women, Non-working women, Consumer right

How to cite this article : Kundle, S., Joglekar, A. and Banerjee, S. (2014).Comparative analysis about consumer rights regarding convenience food among working and non-working women. Food Sci. Res. J., 5(2): 130-134.

\footnotetext{
Author for correspondence :

S. KUNDLE, Department of Home Science, Govt. D.B. Girls P.G College, RAIPUR (C.G.) INDIA

Associate Authors' :

A. JOGLEKAR, Department of Home Science, Govt. G. N. A P. G. College BHATAPARA(C.G.) INDIA

S. BANERJEE, Department of Home Science, Govt. D.B. Girls P.G. College, RAIPUR (C.G.) INDIA
} 